\title{
Degradation of disperse dye from textile effluent by free and immobilized Cucurbita pepo peroxidase
}

\author{
N. Boucherit ${ }^{1 \mathrm{a}, \mathrm{b}}$, M. Abouseoud ${ }^{\mathrm{b}, \mathrm{c}}$ and L. Adour ${ }^{\mathrm{a}, \mathrm{d}}$ \\ ${ }^{a}$ Université Mouloud Mammeri, Tizi-Ouzou, Algérie. \\ ${ }^{\mathrm{b}}$ Laboratoire de Biomateriaux et de Phenomènes de Transports, Université Dr. Yahia Fares, Médéa, \\ ALGERIE. \\ ${ }^{\mathrm{c}}$ Laboratoire de Génie de la Réaction, Faculté de Génie Mécanique et Génie des Procédés, USTHB, \\ Bab Ezzouar, Alger, 16111 AlGERIE \\ ${ }^{\mathrm{d}}$ Laboratoire des Biotechnologies Environnementales et Génie des Procédés, BIOGEP, ENP, El- \\ Harrach, ALGERIE
}

\begin{abstract}
Disperse dyes constitute the largest group of dyes used in local textile industry. This work evaluates the potential of the Cucurbita peroxidase(C-peroxidase) extracted from courgette in the decolourization of disperse dye in free and immobilized form. The optimal conditions for immobilization of C-peroxidase in Ca-alginate were identified. The immobilization was optimized at $2 \%(\mathrm{w} / \mathrm{v})$ of sodium alginate and $0.2 \mathrm{M}$ of calcium chloride. After optimization of treatment parameters, the results indicate that at $\mathrm{pH} 2$, dye concentration: $80 \mathrm{mg} / \mathrm{L}$ (for FCP) and $180 \mathrm{mg} / \mathrm{L}$ (for ICP), $\mathrm{H}_{2} \mathrm{O}_{2}$ dose: $0,02 \mathrm{M}$ (for FCP) and $0,12 \mathrm{M}$ (for ICP), the decolourization by free and immobilized Cperoxidase were $72.02 \%$ and $69.71 \%$ respectively. The degradation pathway and the metabolic products formed after the degradation were also predicted using UV-vis spectroscopy analysis.
\end{abstract}

\section{Introduction}

Dye Effluent from textile industry, is one of important sources of pollution, which are charged by colored and contaminants that must treated. Remediation of dye wastewater by physical and chemical methods has been applied in most studies [1-9]. These methods present some drawbacks of being economically unfeasible, and being unable to completely remove the recalcitrant azo dyes and/or their organic metabolites, generating a significant amount of sludge that may cause secondary pollution problems, and involving complicated procedures [10,11]. Also, the microbiological treatment methods, present low removal decolourization efficiency, because of toxicity of the majority of dye to micro-organism and high cost of process.

Some of study, propose to use enzymes with minimum toxicity properties, in order to remove dyes from polluted water with high efficiency and rate of degradation such as: peroxidases, laccases, azoreductases and oxidases, originated from plant and microorganisms sources [12-20].

Peroxidases preparation from plant, especially: horse radish, turnip and bitter gourd, are widely used to remove and degrade complex aromatics compounds [21-23]. Therefore, attention came on

\footnotetext{
1 e-mail : na_boucherit@yahoo.fr
} 
immobilization of peroxidase for the purpose of aromatic compound removal, [24-27]. This application is one of the strategies known to increase enzyme stability against the inactivation mediated by various types of denaturants and reusability by application in batch and continuous bioreactor. Another advantageous properties of immobilized peroxidase, is their separation from soluble reaction products and untreated substrate.

Alginates appear to be one of the most suitable polymers for the immobilization technology because of their hydrophilic properties, natural origin and stability over extreme experimental conditions, $[28,29]$.

The aim of the present study, was to extract a new peroxidase, from fruit organs of Cucurbita pepo and optimize it immobilization in beads of calcium alginate. Thus, we attempt to developed an inexpensive and efficient method for treatment of disperse dye that is potentially toxic and even carcinogenic by free and immobilized C-peroxidase. Effects of parameters such as : aqueous phase $\mathrm{pH}$, substrates and enzyme concentrations, contact time, repeated application of immobilized enzyme, have been investigated to optimize the system conditions.

\section{Materials and methods}

\subsection{Materials}

Blue Marine Bemacron, commercial name of disperse dye, was gift from Bezema AG. Acetone, buffers solutions, hydrogen peroxide, calcium chloride hexahydrate were obtained from Sigma Chemical Co. (St. Louis, MO, USA) and others chemicals were of analytical grade and were used without further purification.

C-Peroxidase was extracted from fresh courgette vegetal, collect from local market.

\subsection{Methods}

\subsubsection{Extraction, purification and activity assay of C-peroxidase}

Courgette $(100 \mathrm{~g})$ were crushed in a wet grinder with addition of $200 \mathrm{ml}$ of buffer solution(pH 6), and the extract was filtered through multi-layers of cheese cloth. Then, it was partially purified using acetone precipitation technique at $4{ }^{\circ} \mathrm{C}$, and then centrifuged at the speed of 5,000 rpm for $30 \mathrm{~min}$ at $4^{\circ} \mathrm{C}$. Activity of free and immobilized C-peroxidase was assessed by employing 4-aminoantipyrene method involving colorimetric estimation using phenol and hydrogen peroxide as substrates and 4aminoantipyrene as chromogen, [30].

\subsubsection{Immobilization of C-peroxidase: Calcium alginate gel entrapment}

Calcium alginate beads were prepared by extrusion process that described by Nigma et al, [31]. Sodium alginate dissolved in $10 \mathrm{ml}$ of enzymatic solution, was prepared in a backer equipped with a magnetic stirrer. Dissolving process is took up to $2 \mathrm{~h}$ for preparing a different concentrations $(1,2,3$, $4 \%)(\mathrm{w} / \mathrm{v})$ of alginate/enzyme. Finally, the gel was dropped through a syringe into $50 \mathrm{ml}$ of calcium chloride solution with different molar concentrations $(0.1 \mathrm{M}, 0.2 \mathrm{M}, 0.3 \mathrm{M})$ under permanent magnetic agitation for $2 \mathrm{~h}$ forming beads of $2,0-3,0 \mathrm{~mm}$ of diameter(Figure 1). The obtained beads were filtered with distilled water and keep in buffer solution $\mathrm{pH} 7$ at $4^{\circ} \mathrm{C}$. The enzyme immobilization efficiency was assess by measure of the activity of $\mathrm{C}$-peroxidase both in calcium chloride solution and beads. It was calculated from the equation (1):

$$
E_{\text {im }}=\left(\frac{A_{\text {initiale solution }}-A_{\mathrm{CaCl}_{2}}}{A_{\text {initiale solution }}}\right) \times 100
$$




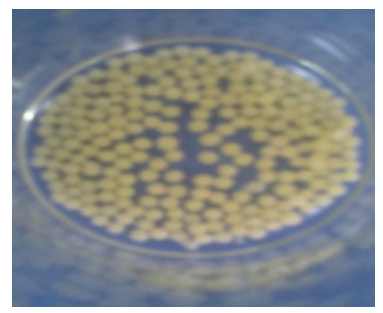

Fig. 1. Photo of some alginate immobilized enzyme

\subsubsection{Assay of enzymatic dye degradation}

Batch experiments were conducted in a glass beakers containing $0.1 \mathrm{~L}$ of the reaction synthetic mixture and stirred with permanent magnetic agitation at 300rpm during a fixed duration. These experiments were carried out at different conditions: initial BMB concentration (16-220mg/L), $\mathrm{H}_{2} \mathrm{O}_{2}$ dose $(0,4-200 \mathrm{mM})$ and initial $\mathrm{pH}$ fixed in rang of 2 to 10 . C-peroxidase activity at $25^{\circ} \mathrm{C}$ was fixed in rang of 0,06 to $2,27 \mathrm{UI} / \mathrm{ml}$ and $0,53 \mathrm{UI} / \mathrm{ml}$. The reaction was stopped by keeping in a boiling water bath during $5 \mathrm{~min}$.

The effect of $\mathrm{pH}$ on decolourization yield was investigated by performing different type of buffers including: $50 \mathrm{mM}$ of potassium chloride/ $\mathrm{HCl}$ buffer $(\mathrm{pH} 2), 50 \mathrm{mM}$ of $\mathrm{HCl} / \mathrm{phtalate}$ buffer (pH3 and $\mathrm{pH} 4), 50 \mathrm{mM}$ of phosphate buffer ( $\mathrm{pH} 6,7$ and 8$), 50 \mathrm{mM}$ of borax/NaOH buffer ( $\mathrm{pH} 9$ and 10). After centrifugation at $4000 \mathrm{rpm}$ during $10 \mathrm{~min}$, the residual dye concentration after treatment with free and immobilized C-peroxidase was carried out by UV-vis spectrophotometer (PerkinElmer 550A ) at the maximum wavelengths $622 \mathrm{~nm}$. The initial decolourization rate (IDR) on treated dye by FCP and ICP was calculated from the slope of the dye concentration versus time, at the beginning of decolourization. So efficiency of decolourization was calculated from the equation (2):

$$
E D=\left(\frac{A_{0}-A_{t}}{A_{0}}\right) \times 100
$$

$\mathrm{A}_{0}$ : absorbance at $622 \mathrm{~nm}$ of dye before treatment

$\mathrm{A}_{\mathrm{t}}$ : absorbance at $622 \mathrm{~nm}$ of dye after treatment

\section{Results and discussions}

\subsection{Optimization of immobilization}

For an activity of free C-peroxidase of $2.51 \mathrm{UI} / \mathrm{ml}$, different concentrations of sodium alginate and calcium chloride solution were used to obtained the optimal condition for producing biocatalysts, effective in dye removal from aqueous phase. In order to find this concentration three factors were taken into consideration: immobilization efficiency, retention efficiency and enzyme leakage. Results on the effect of sodium alginate and calcium chloride concentrations on the biocatalyst characteristics are presented in table 1 .

According to table 1 , for fixed concentration of calcium chloride $(0.1 \mathrm{M})$, the increasing of alginate concentration from 2 to $4 \%(\mathrm{v} / \mathrm{w})$, reduces the retention capacity and enzyme activity, but did not have a significant influence on immobilization efficiency. This might be due to a limitation of substrate transfer from the bulk phase into the alginate bead to access the enzyme. For a concentration of $2 \%$ of alginate, the changes in enzyme retention and enzyme leakage were influenced by calcium chloride concentration, the higher one gives the lower enzyme leakage [28]. 
The best biocatalytic properties including higher enzyme immobilization and lower enzyme leakage were achieved when the calcium chloride and sodium alginate solution were $0.2 \mathrm{M}$ and $2 \%(w / v)$ respectively. To confirm this result, the figure. 2 show that the stability of beads was conserved since the activity was persistent and leakage was minimal during three months. For the beads obtained under conditions ( $2 \%$ and $0.1 \mathrm{M}$ of alginate and calcium chloride), a $50 \%$ leakage was reached after 7 days.

\subsection{Dye degradation with free and immobilized C-peroxidase}

\subsubsection{Optimum $\mathrm{pH}$, dye, $\mathrm{H}_{2} \mathrm{O}_{2}$, enzyme concentrations and time duration}

Enzymes have an optimum $\mathrm{pH}$ range at which their activity is maximum, this enzymatic activity is estimated to a maximum of the dye decolourization for a range of acidic $\mathrm{pH}(\mathrm{pH} 2)$ for both FCP and ICP(figure 2). This result corroborates the work carried out by De Souza et al.[12] and Maddhinni et al.[33] who studied enzymatic removal of Remazol Turquoise Blue G133, Lanaset Blue 2R and Direct yellow 12 by horse radish peroxidase, and it was conducted that acidic $\mathrm{pH}$ is a suitable medium for the treatment, above this range the peroxidase activity was inhibited. Thus, for treated disperse dyes: Disperse Red 19 and Disperse Black 9 by gourd peroxidase, the maximum of decolourization was obtained at acidic $\mathrm{pH}$, [34].

Table 1. Activity of beads of C-peroxidase, immobilization and retention efficiency and leakage of the beads obtained under different gelation conditions.

\begin{tabular}{|c|c|c|c|c|}
\hline Test 1 & \multicolumn{4}{|c|}{ Calcium chloride $(0.1 \mathrm{M})$} \\
\hline Sodium alginate concentration $(\mathrm{w} / \mathrm{v})$ & $1.5 \%$ & $2 \%$ & $3 \%$ & $4 \%$ \\
\hline Immobilization $\%$ & 74,10 & 90,80 & 73,03 & 89,46 \\
\hline Retention activity $\%$ & 28,52 & 35,42 & 18,98 & 3,66 \\
\hline Immobilized C-peroxidase activity (UI/ml) & 0,716 & 0,89 & 0,47 & 0,092 \\
\hline Leakage $(\%)$ & 9,52 & 4,97 & 9,97 & 1,25 \\
\hline Test 2 & \multicolumn{4}{|c|}{ Sodiumalginate concentration $2 \%(w / v)$} \\
\hline Calcium chloride $(\mathrm{M})$ & 0.1 & \multicolumn{2}{|c|}{0.2} & 0.3 \\
\hline Immobilization $\%$ & 90,80 & \multicolumn{2}{|c|}{75} & 74 \\
\hline Retention activity $\%$ & 35,42 & \multicolumn{2}{|c|}{21,23} & 16,11 \\
\hline Immobilized C-peroxidase activity (UI/ml) & 0,89 & \multicolumn{2}{|c|}{0,53} & 0,40 \\
\hline Leakage (\%) & 4,97 & \multicolumn{2}{|c|}{6,19} & 4,95 \\
\hline
\end{tabular}




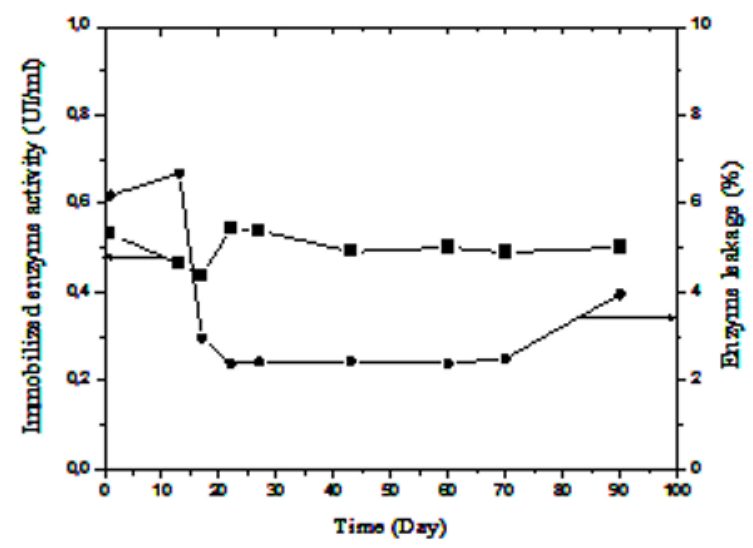

Fig. 2. Stability test of beads of C-peroxidase (calcium chloride and sodium alginate concentration: $0.2 \mathrm{M}$ and $2 \%(\mathrm{w} / \mathrm{v})$ respectively) representing by enzyme leakage and immobilized enzyme activity.

High decolourization by C-peroxidase was achieved at low concentration of BMB and decolourization efficiency dropped at higher dye concentration (Figure 3a). However, initial decolourization rate was increased with the increasing of dye concentration, this is was also observed in decolourization by other peroxidases [ $34,35,36]$. The optimum dye concentration was selected for maximum IRD and. $E$, it has a value of $80 \mathrm{mg} / \mathrm{L}$ and $180 \mathrm{mg} / \mathrm{L}$ for FCP and ICP respectively (Figure 3). Further, C-peroxidase can catalyze the dye removal reaction at high concentration with medium affinity especially in the immobilized form.
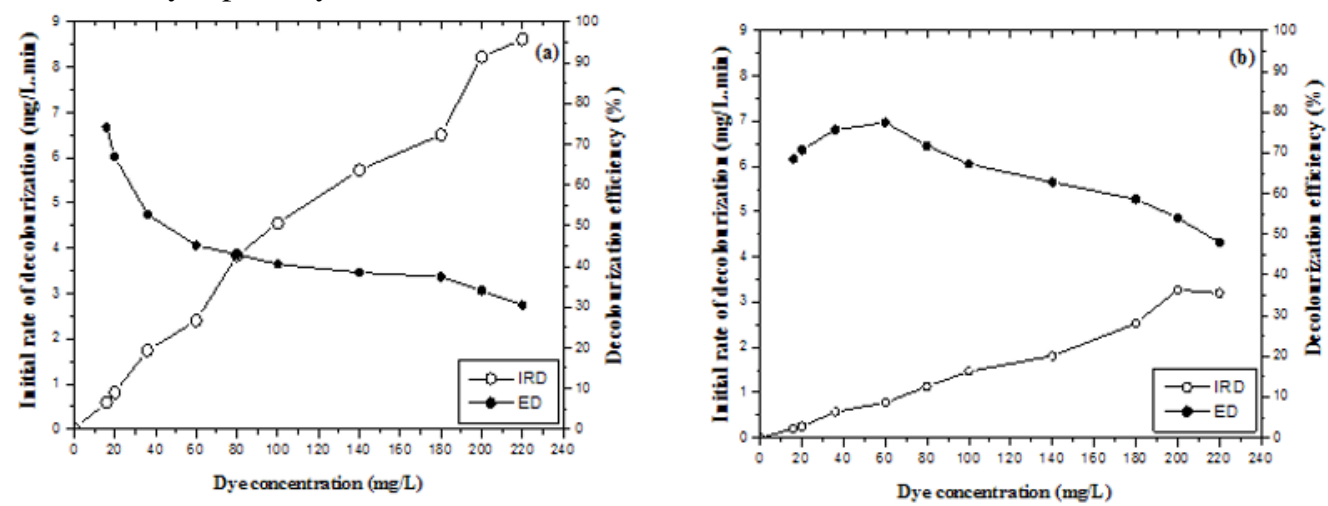

Fig. 3. Effect of dye concentration on (IRD) and (ED) for free (a) and immobilized C-peroxidase (b). ( ( $\mathrm{pH}=2$, $\mathrm{H}_{2} \mathrm{O}_{2}=0,02 \mathrm{M}$ (FCP and ICP), $\mathrm{T}=20^{\circ} \mathrm{C}, \mathrm{EA}=0,88 \mathrm{UI} / \mathrm{ml}$ (for FCP), contact times: $5 \mathrm{mn}$ (FCP) and $35 \mathrm{mn}$ (ICP)).

In order to find out optimum $\mathrm{H}_{2} \mathrm{O}_{2}$ concentration, experiments were carried out by varying concentration of $\mathrm{H}_{2} \mathrm{O}_{2}$ and keeping others experiment conditions at fixed values. The hydrogen peroxide was considerate as co-substrate, it contributes in the catalytic cycle of peroxidase, to oxidize the native enzyme to form an enzymatic intermediate witch accept the aromatic compound to carry out its oxidation to form a free radical form. The results were demonstrate that the hydrogen peroxide has a slight effect on removal dye; however, the immobilized form have the advantage to protect enzyme against high hydrogen peroxide concentration giving higher decolourization yield but at lower rates. For this later case, The $\mathrm{H}_{2} \mathrm{O}_{2}$ dose $(0,12 \mathrm{M})$ corresponding to a high dye removal $(>72 \%)$ compared to free form $(0,02 \mathrm{M}$ with $43 \%$ of decolourization), (figure 4$)$.

The optimization of the quantity of enzyme was carried out. The aim was to obtain a lower enzyme quantity in free form at a high efficiency of decolourization. From the figure 5, it was 
observed that when the concentration studied was $0,3738 \mathrm{UI} / \mathrm{ml}$ the decolourization of the dye was $27.25 \%$; however, when the concentration was doubled the decolourization has also doubled, but when the catalytic activity reaches $1,73 \mathrm{UI} / \mathrm{ml}$, decolourization varies in range: (69-72)\%.
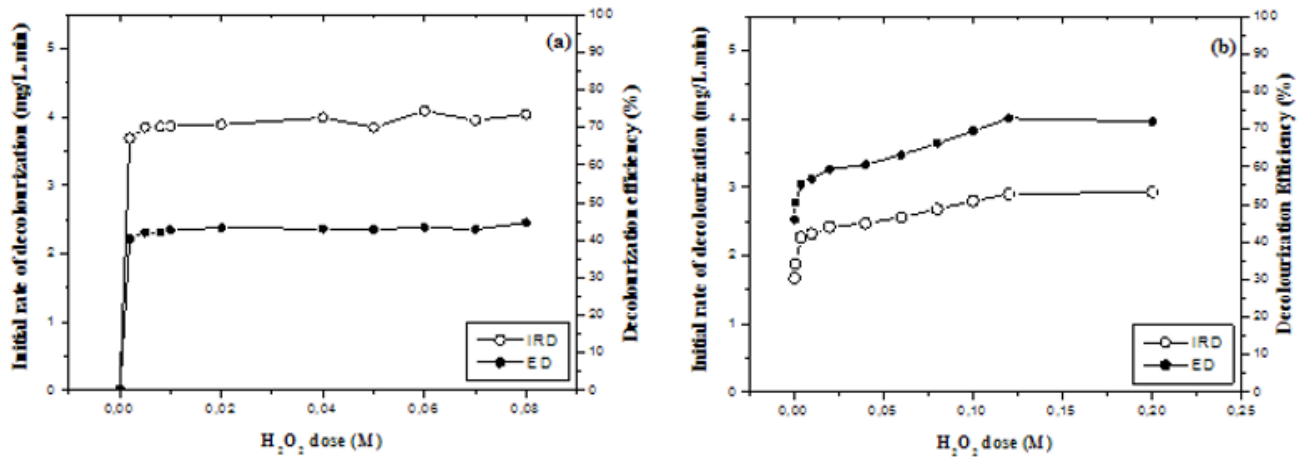

Fig. 4. Effect of peroxide hydrogen concentration on IRD and ED for free (a) and immobilized Cperoxidase (b) $\left(\mathrm{pH}=2\right.$, dye concentrations: $80 \mathrm{mg} / \mathrm{l}(\mathrm{FCP})$ and $180 \mathrm{mg} / \mathrm{l}(\mathrm{ICP}), \mathrm{T}=20^{\circ} \mathrm{C}, \mathrm{EA}=0,88 \mathrm{UI} / \mathrm{ml}$ (for FCP), contact times: $5 \mathrm{mn}$ (FCP) and 35mn (ICP))

Another important factor is the enzyme-substrate contact time which gives a maximum removal. After optimization of parameters, contact time is reduced for immobilized C-peroxidase from $35 \mathrm{~min}$ to 15 min with increasing decolourization more than $10 \%$ (figure 6). Different results could be obtained with other types of dyes/peroxidases [32].

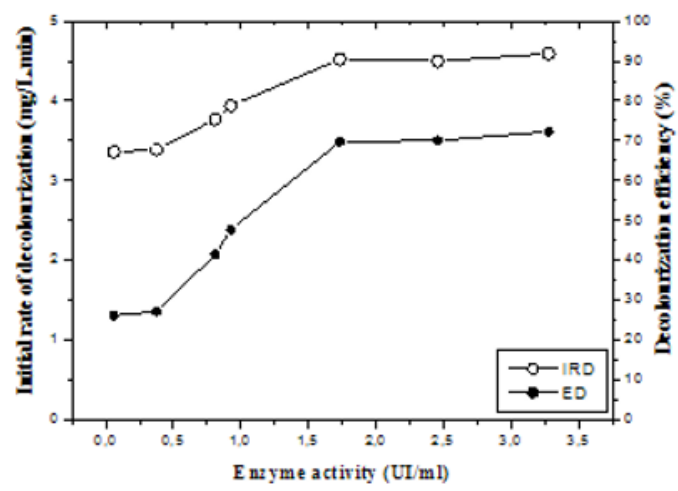

Fig. 5. Effect of FCP dose on IRD and DE (contact time: $5 \mathrm{mn}, \mathrm{pH}=2, \mathrm{~T}=20^{\circ} \mathrm{C}, \mathrm{H}_{2} \mathrm{O}_{2}: 0,02 \mathrm{M}$, initial dye concentration: $80 \mathrm{mg} / \mathrm{L}$ ).

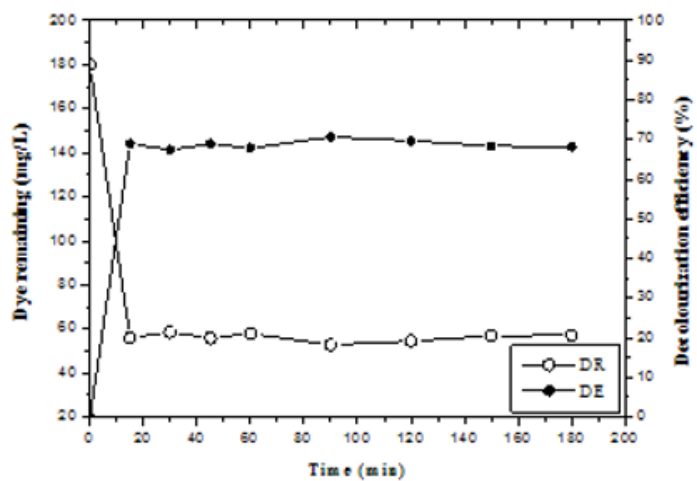

Fig. 6. Dye remaining and efficiency of decolourization pattern with ICP a function contact time $\left(\mathrm{pH}=2, \mathrm{~T}=20^{\circ} \mathrm{C}\right.$, $\mathrm{H}_{2} \mathrm{O}_{2}=0,12 \mathrm{M}$, initial dye concentration $=180 \mathrm{mg} / \mathrm{L}$ ).

\subsubsection{UV-vis spectra analysis}

The scanning spectra of the BMB solution before and after treatment are shown in figure 7 . The test was carried out at optimum conditions of free C-peroxidase. The result depicts a significant color removal by breakage of $-\mathrm{N}=\mathrm{N}$ - chromophore ( $>72 \%$ of dye removal). The spectrum of treated dye in UV region ( at 200, 225 and $254 \mathrm{~nm}$ ) show a decreasing in absorbance with comparison with untreated dye, this is may be considered as a partial mineralization of the dye after enzymatic treatment, [37]. 


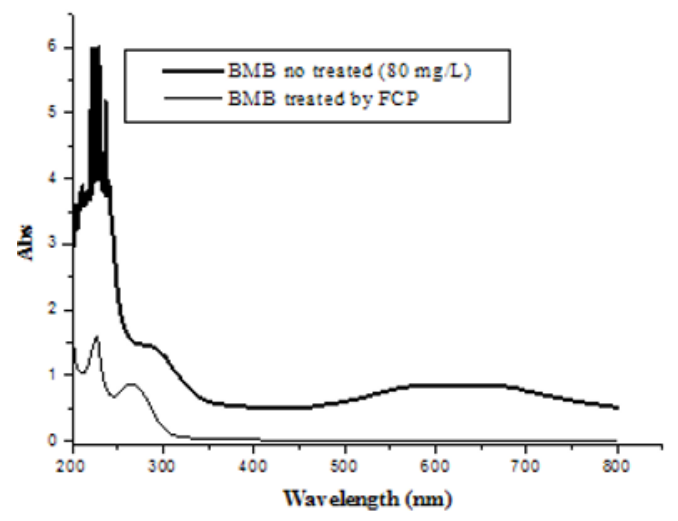

Fig. 7. UV-vis spectrum of BMB presenting original dye $(80 \mathrm{mg} / \mathrm{L})$ and enzymatic treated dye by $\mathrm{FCP}$ at $\mathrm{pH}=2$, $\mathrm{EA}=1,73 \mathrm{UI} / \mathrm{ml}, \mathrm{T}=20^{\circ} \mathrm{C},\left[\mathrm{H}_{2} \mathrm{O}_{2}\right]=0,02 \mathrm{M}$ and $\mathrm{t}=5 \mathrm{~min}$

\subsubsection{Reusability of immobilized C-peroxidase}

Figure 8, shown reusability of ICP for treatment of BMB. After 5th repeated use, the ICP retained $71 \%$ dye decolourization capacity, it was slowly decreasing and remained invariants even up 10 uses. Other investigators for immobilized bitter gourd peroxidase were found that $59 \%$ of textile effluent was removed after $8^{\text {th }}$ repeated use, [38].

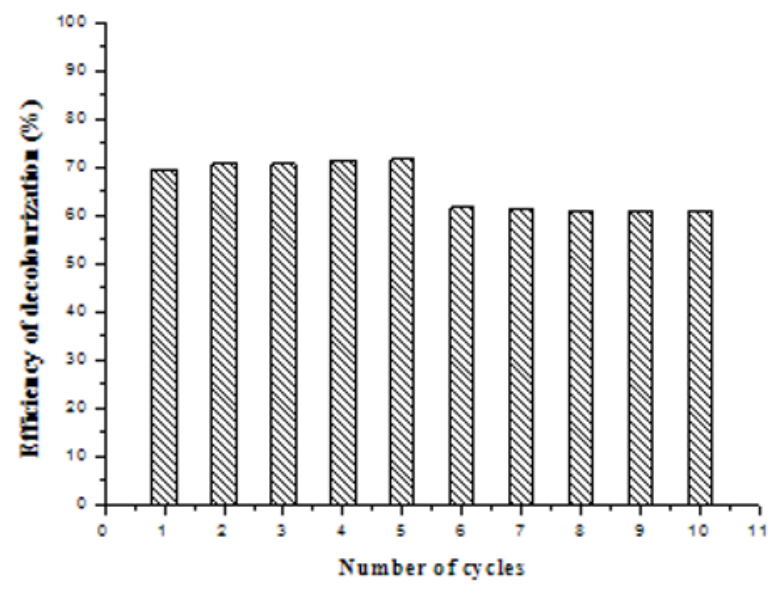

Fig. 8. Reusability of ICP for the treatment of disperse dye at $\mathrm{pH}=2, \mathrm{~T}=20^{\circ} \mathrm{C}, \mathrm{H}_{2} \mathrm{O}_{2}=0,12 \mathrm{M}$ and initial dye concentration $=180 \mathrm{mg} / \mathrm{L}$.

\section{Conclusion}

The preparation, optimization of immobilized C-peroxidase in Ca-alginate beads and it application on treatment of disperse dye from aqueous solutions was investigated. The results obtained in the present study revealed the effectiveness of the immobilized C-peroxidase in BMB decolourization.

Enzyme retention activity, bead activity, immobilization and leakage efficiency are influenced by the gel preparation conditions. The performance of BMB removed for both free and encapsulated Cperoxidase was found to be highly dependent on dye and enzyme concentrations, and aqueous phase $\mathrm{pH}$ with presence of $\mathrm{H}_{2} \mathrm{O}_{2}$. The catalytic properties for dye treatment with immobilized enzyme can 
remain relatively constant after ten cycles of repeated batches, with slight deficiency in catalytic performance of enzyme.

\section{References}

1. T. Robinson, G. McMullan, R. Marchant, P. Nigam. Biores. Technol.77, 247-255 (2001)

2. T. Robinson, B. Chandran, P. Nigam. Water. Res, 36, 2824-2830(2002)

3. S. H. Lin, M.L. Chen,Water. Resour, 31, 868-876(1997)

4. A. P. Vieiraa, S.A.A. Santanaa, C.W.B. Bezerraa, H. A.S. Silva, J. A.P. Chaves, J. C.P. de Melo, E. C. da Silva Filho, C. Airoldi. J. Haz. Mat, 166, 1272-1278 (2009)

5. H-Y. Shu, M-Ch. Chang. J. Haz. Mat, B125, 96-101(2005)

6. H. Zhang, J. Zhang, Ch. Zhang, F. Liu, D. Zhang. Ultrason. Sonochem, 16, 325-330 (2009)

7. S. Vajnhandl, A.M. Le Marechal, Dyes. Pigm, 65, 89-101(2005)

8. S. H. Lin, M. L. Chen, Desalination, 109, 121-130 (1997)

9. M. Perez, F. Torrades, X. Domenechb, J. Peral, Water. Res, 36, 2703-2710(2002)

10. Forgacs,E.,T.Cserhati,andG.Oros, Environ. Int,30,953(2004).

11. Zhang,F.,A.Yediler,X.Liang,andA.Kettrup, Dyes Pigm,60,1(2004)

12. S.Maria.A.G.U. De Souza, E. Forgiarini, A.A.U.De Souza, J. Haz. Mat, 147, 1073-1078(2007).

13. I. Khouni, B. Marrot, P. Moulin, R. Ben Amar. Desalination 268, 27-37(2011)

14. Claus H, Faber G, Konig H,. App. Microbiol. Biotechnol, 59, 672-678(2002)

15. Dayaram P, Dasgupta D, J. Environ. Biol, 29, 831-836(2008)

16. R.G. Saratale, G.D. Saratale, J.S. Chang, S.P. Govindwar. J.Taiwan Inst. Chem. Engineers 42,138-157(2011)

17. A. Khan, Q. Husain. J. Environ. Sci, 19, 396-402(2007)

18. M. Hamid, K. ur-Rehman, Food. Chem, 115, 1177-1186(2009)

19. Q. Husain, Crit. Rev. Biotechnol,60, 201-221(2006)

20. T.S. Shaffiqu, J.J.Roy, R.A.Nair, T.E. Abraham, Appl. Biochem. Biotechnol, 102,103,315326(2002)

21. A. Bhunia, S. Durani, P.P. Wangikar. Biotechnol. Bioeng, 72, 562-567(2001)

22. M. Matto, Q. Husain. Ecotoxicol. Environ. Safety, 72,965-971(2009)

23. S. Akhtar, A. Ali Khan, Q. Husain. Biores. Technol, 96, 1804-1811(2005)

24. S. Akhtar, A. Ali Khan, Q. Husain. Chemosphere, 60, 291-301(2005)

25. M. Matto, Q. Husain. J. Haz. Mat, 164, 1540-1546(2009)

26. M. Shakeri, M. Shoda. J. Mol. Catal. B: Enzymatic, 62, 277-281(2010)

27. Z. Karim, Q. Husain. J. Mol. Catal. B: Enzymatic, 66, 302-310(2010)

28. I. Alemzadeh, S. Nejati. J. Haz. Mat, 166, 1082-1086(2009)

29. Taqieddin E, Amiji M. Biomaterials, 25,1937-1945 (2004)

30. Nicell JA, Wright H. Enzyme. Microb. Technol, 21, 302-310(1997)

31. S.C. Nigma, I.-F. Tsao, A. Sakoda, H.Y. wang, Biotec. Tech, 2, 271-276(1988)

32. V.L. Maddhinni, H.B. Vurimindi, A. Yerramilli. J. Indnian. Sci, 86, (2006) 507-514.

33. F. Jamal, P. Kumar Pandey, T. Qidwai, J. Mol. Catal. B: Enzymatic, 66, 177-181(2010)

34. M.Z. Alam, M.F. Mansor, K.C Jalal, J. Haz. Mat, 162, 708-715(2009)

35. G.Yu, X. Wen, R. Li, Y. Qian,. Process Biochem, 41, 1987-1993(2006)

36. V. Yousefi, H-R. Kariminia, Inter. Biodeterio. Biodegra, 64, 245-252(2010)

37. B. Lodha, S. Chaudhali, J. Haz. Mat, 148, 459-466(2007)

38. M. Matto, Q. Husain. J. Haz. Mat, 164, 1540-1546(2009) 